\title{
OBSERVATIONS ON ROOTLET DEVELOPMENT IN YELLOW BIRCH ${ }^{1}$

\author{
By D. R. REDMOND2
}

\begin{abstract}
Under a closed stand the presence of organic material is more important
\end{abstract} than the prevailing temperature in determining whether a specific volume of soil is occupied by yellow birch rootlets. Most of the organic matter under stands containing birch in the Maritime Provinces is contained in the humus layer, which is rarely more than $6 \mathrm{~cm}$. thick. In pure hardwood stands containing a high proportion of yellow birch, over $75 \%$ of the rootlets were found in the humus layer. In hardwoods containing less birch or in stands containing a high proportion of conifers, over $90 \%$ of the birch rootlets were in the humus.

In previous reports on ecological factors influencing development of roots of yellow birch, Betula lutea Michx. f., it was shown that in pot cultures rootlets developed abundantly only where nutrient supplies were favorable (2), and that in the forest increased mortality of rootlets was caused by small increments in soil temperaturees prevailing in 1953 (3). More recently, observations have been made on the occurrences of rootlets in relation to temperatures prevailing at different depths under birch stands undisturbed by cutting. Data were collected also from stands with different prevailing temperatures. The term "rootlet" is used here to indicate the absorbing root tip, whether mycorrhizal or not.

The information dealing with temperatures in this report was obtained at two locations in each of four different stand types in eastern Nova Scotia. The composition of these stands ranged from that in which yellow birch formed nearly all the dominant trees in a hardwood type to that in which only a few scattered dominant yellow birch remained in a softwood type. Supplemental observations on depth of rootlets were made in central New Brunswick in a hardwood stand where yellow birch comprised about onethird of the upper story.

In the stands in Nova Scotia copper-constantan thermocouples were inserted during May, 1955, into the soil under the crowns of birch trees. Because it is impossible, except by excavation, to determine if a certain soil area contains birch rootlets, it was not known at the time of insertion of the thermocouples whether they were in or under soil occupied by rootlets. As a result, only $105(81.4 \%)$ of the 129 inserted were among yellow birch rootlets. For the same reason, only $12(75 \%)$ of the 16 soil samples taken in New Brunswick contained birch rootlets. Also, it was impossible to predetermine the exact depth at which thermocouples were located and consequently there were layers of soil $1 \mathrm{~cm}$. thick in each stand in which temperature was not recorded.

\footnotetext{
1Contribution No. 338 from the Forest Biology Division, Science Service, Department of Agriculture, Ottawa, Canada.

${ }^{9}$ Forest Biology Laboratory, Fredericton, New Brunswick. Biographical reference: For. Chronicle 30: 79. 1954 .

Received for publication October 29, 1956.
} 
Temperature was recorded daily about mid-day from May 27 to August 28,1955 , and the average of daily readings is given as the average summer temperature (Table I). Surface temperature recorded (Table I) is that in permanent shade on the surface of raw litter. In early September, 1955, a core of soil, $25 \mathrm{~cm}$. deep and $50 \mathrm{sq}$. $\mathrm{cm}$. in cross-sectional area, that contained the buried thermocouple was removed and the number of living rootlets of yellow birch was determined in each $1 \mathrm{~cm}$.-thick layer of soil. The depth of the thermocouple was recorded at this time. All depths were recorded after the raw litter had been removed.

Because no abnormal mortality of rootlets was observed, it would appear that during 1955 the soil in undisturbed stands did not become warm enough over prolonged periods to cause death of yellow birch rootlets, although during one day temperatures as high as $27^{\circ} \mathrm{C}$. were recorded in the humus layers under a pure hardwood stand. The highest temperature recorded in the soil under a softwood stand was $19^{\circ} \mathrm{C}$.

The concentration of rootlets with increasing depth in the soil and the average of temperatures recorded during the season are shown in Table $I$. The average temperatures in the deeper layers of soil (6 to $12 \mathrm{~cm}$.) in stands composed predominantly of hardwoods were as high as or higher than in the upper layers ( 1 to $3 \mathrm{~cm}$.) under stands where conifers predominated. However, the concentration of rootlets was not nearly as high in the warmer but deeper layers under hardwoods as in the cooler layers near the surface under conifers. The highest soil temperatures in each stand were found to be in the upper layers and in general temperature decreased with depth. This indicates that some factor other than temperature (within the range occurring normally) determines the concentration of yellow birch rootlets in a soil layer.

Study of areas where mineral soil had been thrown up by burrowing animals on undisturbed humus some five or six years previously showed that the population of rootlets in the new humus that had formed was approximately the same as in the surrounding humus. Also, the rootlet population in the buried humus was approximately the same at depths up to $15 \mathrm{~cm}$. as in humus on the surface. Rootlets at depth in undisturbed soil were found to develop in decomposing roots of the same or other species. Many of the larger roots were located in the $B$ horizon and some rootlets had developed at the same depth. However, the extremities of these roots extended upward and most of their rootlets were located in the top $5 \mathrm{~cm}$. of soil, the area containing humus.

These data indicate that in a closed stand the content of organic material is more important than soil temperature in determining the location of yellow birch rootlets. Since this organic material is usually at the surface, rootlet populations are highest there. The leaf litter falling in 1953 was found to be fully invaded by rootlets by the end of the 1955 growing season.

Although the highest concentration of rootlets (over $75 \%$ of the total) was always in the humus, statistical comparisons of populations at any depth in the soil could not be made because of the variable thicknesses of the different horizons. For instance, in the four stands sampled in Nova Scotia 
Distribution of Yellow Birch Root DEPTH AND

\begin{tabular}{|c|c|c|c|c|c|c|}
\hline Stand Type & \multicolumn{3}{|c|}{$\begin{array}{c}\text { Hardwood, about } 80 \% \\
\text { Yellow Birch }\end{array}$} & \multicolumn{3}{|c|}{$\begin{array}{l}\text { About } 80 \% \text { Hardwood, } \\
\mathbf{2 0 \%} \text { Spruce and Fir }\end{array}$} \\
\hline Location & \multicolumn{3}{|c|}{ Nova Scotia } & \multicolumn{3}{|c|}{ Nova Scotia } \\
\hline No. of Rootlets & \multicolumn{3}{|c|}{6779} & \multicolumn{3}{|c|}{8457} \\
\hline Soil Horizon & Humus & $\mathbf{A}$ & B & Humus & $\mathbf{A}$ & B \\
\hline $\begin{array}{l}\text { No. of } 50 \mathrm{cc} . \\
\text { Samples of } \\
\text { Soil Examined }\end{array}$ & 110 & 67 & 401 & 80 & 68 & 259 \\
\hline $\begin{array}{l}\text { No. of } 50 \mathrm{cc} \text {. } \\
\text { Samples of } \\
\text { Soil Containing } \\
\text { Rootlets }\end{array}$ & 70 & 4 & 60 & 53 & 1 & 28 \\
\hline $\begin{array}{l}\text { Per cent of } \\
\text { Yellow Birch } \\
\text { Rootlets Oc- } \\
\text { curring }\end{array}$ & 76.3 & 0.7 & 23.0 & 91.8 & 0.1 & 8.1 \\
\hline
\end{tabular}

Average Summer Temperature

\begin{tabular}{|c|c|c|c|c|}
\hline $\begin{array}{c}\text { Depth in } \\
\mathrm{cm} .\end{array}$ & $\begin{array}{c}\text { Average } \\
\text { Temp. } \\
\left({ }^{\circ} \mathrm{C.}\right)\end{array}$ & $\begin{array}{c}\text { Accumulated } \\
\text { Concentration } \\
\text { of Rootlets } \\
(\%) \\
\end{array}$ & $\begin{array}{c}\text { Average } \\
\text { Temp. } \\
\left.\text { ( }{ }^{\circ} \mathrm{C} .\right)\end{array}$ & $\begin{array}{c}\text { Accumulated } \\
\text { Concentration } \\
\text { of Rootlets } \\
(\%)\end{array}$ \\
\hline Surface & 20.8 & - & 19.3 & - \\
\hline $0-1$ & - & 35.3 & 19.1 & 42.1 \\
\hline $1-2$ & - & 60.0 & - & 74.2 \\
\hline $2-3$ & 14.8 & 69.9 & - & 82.4 \\
\hline $3-4$ & - & 75.5 & 14.4 & 89.4 \\
\hline $4-5$ & 14.2 & 79.8 & 16.2 & 91.3 \\
\hline $5-6$ & 14.1 & 81.2 & 15.2 & 93.9 \\
\hline $6-7$ & 14.7 & 82.4 & 14.0 & 94.2 \\
\hline $7-8$ & 14.1 & 83.9 & 15.1 & 94.4 \\
\hline $8-9$ & 14.7 & 85.3 & 15.3 & 95.1 \\
\hline $9-10$ & 14.3 & 87.0 & 15.1 & 95.9 \\
\hline $10-11$ & 14.1 & 87.8 & 11.9 & 96.0 \\
\hline $11-12$ & 128 & 88.9 & 14.6 & 96.3 \\
\hline
\end{tabular}


LE I

lets in Relation to Soll Horizons,

TEMPERATURE

\begin{tabular}{ccc}
\hline $\begin{array}{c}\text { Hardwood-Softwood } \\
\text { Mixture }\end{array}$ & $\begin{array}{c}\text { About 20\% Hardwood, } \\
\mathbf{8 0} \%\end{array}$ Spruce and Fir & $\begin{array}{c}\text { Hardwood, about } \mathbf{3 3} \% \\
\text { Yellow Birch }\end{array}$ \\
\hline Nova Scotia & Nova Scotia & New Brunswick \\
11971 & 5382 & 2327 \\
and Soil Horizons & & \\
\hline
\end{tabular}

\begin{tabular}{|c|c|c|c|c|c|c|c|c|}
\hline Humus & $\mathbf{A}$ & B & Humus & $\mathbf{A}$ & $\mathbf{B}$ & Humus & $\mathbf{A}$ & B \\
\hline 98 & 72 & 324 & 106 & 78 & 338 & 59 & 60 & 116 \\
\hline 85 & 6 & 45 & 58 & 3 & 9 & 24 & 1 & 6 \\
\hline 90.9 & 0.2 & 8.9 & 96.7 & 0.4 & 2.9 & 96.6 & 0.9 & 2.5 \\
\hline
\end{tabular}

and Concentration of Yellow Birch Rootlets

Accumulated Average Concentration Temp. of Rootlets ( $\left.{ }^{\circ} \mathrm{C}.\right)$ (\%)

Accumulated
Average Concentration
Temp. of Rootlets
(\%)

$5 \overline{9.7}$

80.2

93.2

95.6

96.8

97.9

97.9

98.2

98.4

98.4

98.5 99.0
Accumulated Average Concentration Temp. of Rootlets ( $\left.{ }^{\circ} \mathrm{C}.\right) \quad(\%)$

$\begin{array}{rr} & 53.5 \\ & 79.4 \\ \text { Temp. } & 93.7 \\ & 95.5 \\ \text { not } & 97.6 \\ & 97.6 \\ \text { Recorded } & 98.2 \\ & 98.2 \\ & 98.2 \\ & 98.2 \\ & 98.2 \\ & 98.2\end{array}$


the thickness of the humus layer ranged from 1 to $6 \mathrm{~cm}$. (av. 3.2). Likewise the A horizon was of variable thickness, ranging from 1 to $4 \mathrm{~cm}$. (av. 2.0).

The birch trees remaining in the stand in Nova Scotia had undergone a period of severe decline from birch dieback and a large proportion of their roots had died. As a result, it may be considered that the distribution of rootlets as recorded (Table 1) is not representative of that in healthy trees. When the data obtained from Nova Scotia are compared with those from stands in New Brunswick that had not suffered from dieback (Table 1) there seems to be no appreciable difference between rootlet concentration at corresponding depths in the soil. It is shown that $90 \%$ of the rootlets are contained in the top $5 \mathrm{~cm}$. of soil in all stands except the hardwood containing a high proportion of yellow birch. Here, $80 \%$ of the rootlets were within this range of depth.

Information given here confirms that yellow birch is a shallow-rooted species. Because of this rooting habit and the knowledge that this species is sensitive to prolonged but small increases in soil temperature above those normally occurring $(1,3,4)$, it is readily apparent that, if serious loss from decline in vigor and death of yellow birch is to be avoided, care must be taken to protect soil supporting established crop trees from becoming exposed excessively to the sun and wind. It is recommended that any cutting in stands where all birch trees are of merchantable size should be a clear cutting. Improvement cuttings in young stands should be conducted in such a manner that residual trees are exposed as little as possible.

\section{REFERENCES}

1. HALL, R. C. 1933. Post-logging decadence in northern hardwoods. Univ. Mich. School Forestry and Conserv. Bull. 3.

2. REDMOND, D. R. 1954. Variations in development of yellow birch roots in two soil types. Forestry Chron. 30: 401-406.

3. REDMOND, D. R. 1955. Studies in forest pathology. XV. Rootlets, mycorrihiza, and soil temperatures in relation to birch dieback. Can. J. Botany, 33: 595-627.

4. SPAULDING, P AND MACALONEY, H. J. 1931. A study of organic factors concerned in the decadence of birch on cut-over lands in northern New Engand. J. Forestry 29: 1134-1149. 